\title{
NUMERICAL MODELING AND FULL-SCALE EXPERIMENTS OF GLUED WOODEN STRUCTURES JOINT DESTRUCTION ON CARBON-FIBER DOWEL PINS
}

\author{
Mikhail A. Vodiannikov ${ }^{1}$, Galina G. Kashevarova ${ }^{2}$, Danil I. Starobogatov ${ }^{3}$ \\ ${ }^{1}$ Perm National Research Polytechnic University, JSC "VNII Galurgii”; Perm, RUSSIA; \\ ${ }^{2}$ Perm National Research Polytechnic University, Perm, RUSSIA; \\ ${ }^{3}$ Durham College, Ontario, CANADA
}

\begin{abstract}
This paper presents the results of numerical modeling and full-scale experiments of the failure process of a glued laminated timber beam with rigid joint in the middle. All the connecting parts are made of carbon fiber. The structural analysis is done with the finite element method (ANSYS software). The nonlinear problem was solved. The contact interaction of the structural elements in the process of deformation and fracture, as well as orthotropy of the wood, the transversely isotropic properties of the plates, and the real diagrams of the deformation of carbon fiber dowel pins were taken into account. The influence of the structural parameters of the joint on the position of the most loaded dowel pin in the joint and the bearing capacity of the general structure are investigated. To verify the structural analysis results, field tests were carried out before destruction by a stepwise increasing load on a personally designed stand. The destruction of the structure occurred according to the forecast of the numerical model as a result of the mutual slip of the glued wood layers and the destruction of the polymer matrix of the glued dowel pins with the beginning of the formation of plastic joints and the formation of cracks in the wood at the junction.
\end{abstract}

Keywords: wood, carbon fiber, computer model, ANSYS, finite element analysis, composite material, contact

\section{ЧИСЛЕННОЕ МОДЕЛИРОВАНИЕ И НАТУРНЫЕ ЭКСПЕРИМЕНТЫ РАЗРУШЕНИЯ СТЫКОВ КЛЕЕНЫХ ДЕРЕВЯННЫХ КОНСТРУКЦИЙ НА УГЛЕПЛАСТИКОВЫХ НАГЕЛЯХ}

\author{
Водянников М.А. ${ }^{1,2}$, Качеварова Г.Г. ${ }^{1}$, Старобогатов Д.И. ${ }^{3}$ \\ ${ }^{1}$ Пермский национальный исследовательский политехнический университет, г. Пермь, РОССИЯ \\ ${ }^{2}$ АО «ВНИИ Галургии», г. Пермь, РОССИЯ \\ ${ }^{3}$ Durham College, г. Онтарио, КАНАДА
}

\begin{abstract}
Аннотация: В данной работе представлены результаты численного моделирования и натурных экспериментов процесса разрушения конструкции балки из клееной древесины с нагельным стыком, соединительные элементы которого изготовлены из углепластика. Расчеты проводились методом конечных элементов в программном комплексе ANSYS. Решалась нелинейная задача. Учитывалось контактное взаимодействие составляющих элементов конструкции в процессе деформирования и разрушения, а также ортотропия древесины, трансверсально-изотропные свойства пластин, реальные диаграммы деформирования углепластиковых нагелей. Исследовано влияние конструктивных параметров стыка на положение наиболее нагруженного стержня в соединении и несущую способность конструкции балки. Для верификации результатов расчета проводились натурные испытания балок до разрушения пошагово возрастающей нагрузкой на специально запроектированном стенде. Разрушение конструкции произошло согласно прогнозу численной модели в результате взаимного проскальзывания слоев клееной древесины и разрушения полимерной матрицы вклеиваемых стержней с началом образования пластических шарниров под пятками траверсы и образованием трещин в древесине в месте стыка.
\end{abstract}

Ключевые слова: древесина, углепластик, компьютерная модель, ANSYS, конечноэлементное моделирование, композитный материал, контакт 


\section{INTRODUCTION}

Joints of solid and glued timber structures are the most responsible and extremely labor-intensive design section in the construction of long-span architectural forms. Numerous studies of wooden structures joints were carried out by such institutions as VIAM, TSNIISK, TsAGI, MISI, LISI, VIA and researchers: G. G. Carlsen, I. P. Kulibin, V. G. Shukhov, V. M. Kochenov; Gestesi, Earl, Schnidtman and others.

S. A. Andreev [1], V. N. Maslov [2], V. F. Ivanov [3], B. L. Nikolai [4], A. V. Lenyashin [5], V. G Donchenko [6], Yu. V. Slitskoukhov [7]) considered a dowel as a beam on an elastic base.

G. G. Carlsen was the first to propose a method for calculating joints by permissible stresses. V. M. Kochenov [8] proposed a methodology for calculating nugget joints taking into account the elastic-plastic work of wood in the nest for collapse and the plastic work of rods for bending.

The authors S. B. Turkovskii and A. A. Pogoreltsev [10-13] proposed a universal joint on glued rods ("TsNIISK system") using steel pins and overlays (Figure 1), which made it possible to create a large number of unique large-span wood structures.

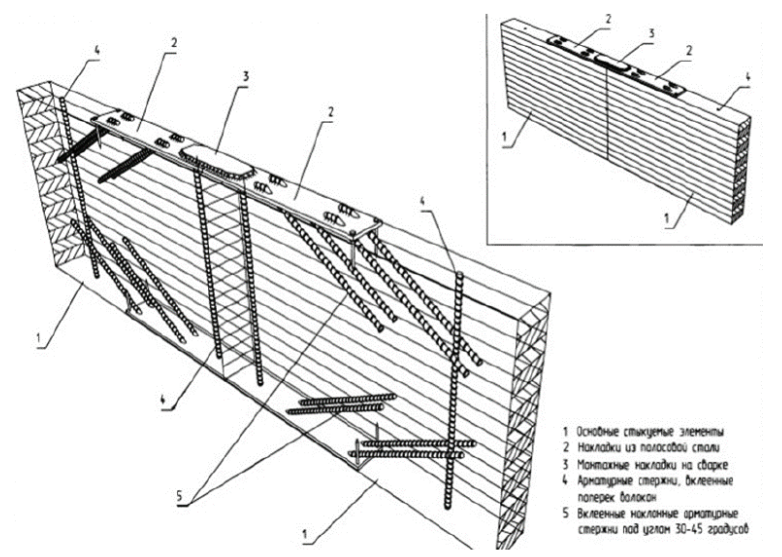

Figure 1. Universal joint "TsNIISK system".

Despite the multipurpose of such compounds, their practical use in load-bearing structures in some cases (chemically aggressive environment, high humidity, etc.) is not reliable, since there is a risk of premature failure of the structure due to corrosion of steel parts. The restoration of the anticorrosion layer is often impossible without stopping the operation of the facility. The hightemperature effect when using steel parts at the joints of the weld joint (patch pads, reinforcing bars) leads to stress concentrators associated with the destruction of the wood structure in these areas. A significant difference in the linear thermal expansion coefficients $\alpha^{*} 106(1 / 0 \mathrm{C})$ of steel (13.0) and wood parallel to the fibers (3.7) leads to a limitation of the joining of largeassembled large-span elements under conditions of a large annual temperature difference. The fire resistance of a massive wooden section treated with flame retardant allows structures to withstand up to 60 minutes without collapse, while the transition of steel connecting parts to a plastic state in a fire will occur 5-12 times less (depending on temperature).

In $[14,15]$, it was shown that it is mainly possible to use composite materials (carbon fiber, basalt, fiberglass) instead of steel to create equal strength joints of wooden structures [16]. But the widespread use of composites today is hindered by the lack of a full regulatory framework, a relatively high cost, a small number of industries and limited application experience. The issue of improving the connections of solid and glued wood structures using glued rods and pads made of composite materials (including carbon fiber reinforced plastics) is relevant and expands the possibilities of using renewable natural materials.

The existing methodology for calculating the connections of the "TsNIISK system" is reduced to comparing the minimum bearing capacity of a rod from the condition of crushing a wood point or bending, the most loaded of rods. However, methods for determining the forces in the pins to find the most loaded rod in the normative documents are not given [17].

The study of the processes of deformation and fracture of a structure under complex stress conditions requires the use of adequate mathematical models of the mechanical behavior of materials and a high degree of detail of structural elements. The use of numerical methods, the 
Numerical Modelling and Full-Scale Experiments of Glued Wooden Structures Joint Destruction of Carbon-Fiber Dowel Pins

capabilities of modern software systems and computers allows us to describe with high accuracy the behavior of the elements of the joint structure in a complex stress state. To analyze the stress-strain state of the structure, the finite element method in the form of the displacement method and "ANSYS" program complex [18], verified at the Russian Academy of Architecture and Building Sciences, was used.

The purpose of this study is to determine the stress-strain state of the elements of the rigid joint of glued wooden structures using composite parts with numerical modeling and a fullscale experiment. To show the fundamental possibility of using composite parts and rods as an alternative to steel elements when creating equal strength assemblies.

To achieve this goal, the following tasks were solved:

1. Creating a design model for the construction of a wooden beam with a joint node, taking into account the orthotropy of glued wood and the contact of the elements of the joint.

2. Structural analysis of the stress-strain state of the structure with different configuration options using four-point bending.

3. To determine the places of the most possible destruction of the structure depending on the parameters of the joint design.

4. To verify the results obtained, conduct fullscale experiments and a comparative analysis with the engineering calculation method.

\section{METHODS}

In this study, a calculated finite-element model of a layered wooden beam with a joint in the middle of the span was created. It was tested using the four-point bending technique (Figure 2a). The model was built in AutoCAD and exported to ANSYS using macros written in the parametric programming language APDL. The joint overview is shown in Figure $2 b$.

The main feature of the considered structure is the contact interaction of bodies [19], the inclusion of which allows to simulate the behavior of its constituent elements in the process of deformation and fracture.

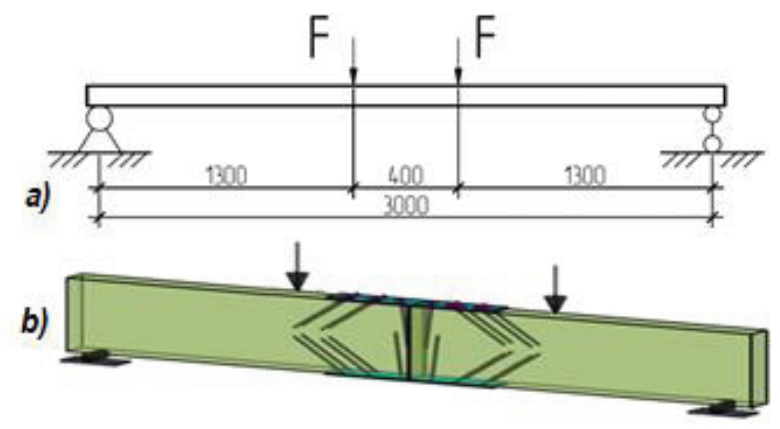

\section{Figure 2. The design scheme of the beam and} joint overview.

The stress state in the contact zones is extremely diverse. Surfaces can come in and out of contact all of a sudden. The stress state is significantly affected by friction, and it must be taken into account.

At the joint boundaries of the contacting elements, distributed surface forces arise. Normal $t_{n}$ and tangent $t_{t}$ components of the distributed contact force acting on any element have the form:

$$
\begin{aligned}
& t_{n}=t \cdot n \leq 0 \\
& t_{t}=t \cdot \tau,
\end{aligned}
$$

where $n$ - external normal to the contact surface of the body, $\tau$ - tangent vector to the contact surface of the body.

In equation (1), non-strict inequality turns into equality when the bodies exit the contact and into strict inequality when they are in contact. Tangent contact forces can take any value. The application of the tangential stress in the contact does not lead to slippage, provided that the bodies in the contact area are glued to each other or the friction coefficient tends to infinity. In this case, the tangential contact forces are independent of normal contact forces, but are not equal to zero.

The contacting bodies are motionless relative to each other, i.e. tangential forces obey Coulomb's law as long as the inequality holds: 


$$
\left|t_{t}\right| \leq \mu_{s} \mid t_{n}
$$

where $\mu_{s}>0$-static coefficient of friction. If inequality (1) is violated, the bodies begin to move relative to each other. Then the tangential contact forces obey the following equality:

$$
\left|t_{t}\right|=\mu_{d}\left|t_{n}\right|
$$

where $\mu_{d}-$ dynamic coefficient of friction, $\mu_{d} \leq \mu_{s}$.

The movement will continue until inequality is fulfilled and will not start again until inequality is violated again (3).

$$
\left|t_{t}\right|<\mu_{d}\left|t_{n}\right|
$$

When friction in the contact zones is taken into account, the solution of the problem substantially depends on the sequence of application of external loads, and complex loading programs are implemented at the points entering and leaving the contact [20 - 22].

The development trend of leading software systems (PCs) is the implementation of a set of mathematical models in them to describe different physical processes. The user connects the necessary models at the stage of setting the problem, setting the corresponding boundary conditions and other required input data.

The ANSYS Workbench software module contains a large set of contact technology tools integrated into the finite element method for developing various contact options [7, 8]. Two interacting surfaces are distinguished in a contact $-\mathrm{a}$ contact pair. One of the surfaces is conventionally called "contact" and the second - "target". The choice of contact model is the most important issue in solving contact problems.

In this task the contact area can change and in the general case it contains both adhesion and sliding sections that occur when the module exceeds the tangential force of the limit value of the friction force (rest friction). To model contact interaction and sliding between threedimensional surfaces, the Frictional model and contact elements CONTA174 and TARGE170 were used. The friction coefficient depends on the materials, and is adopted for a pair of woodcarbon fiber -0.25 , and for a pair of woodwood -0.33 .

The following finite elements were used to create the calculated finite element model of the model: the beam body was modeled with 8 -node SOLID185 elements, the rods with 3-node BEAM188 elements, and the pads with 8-node SHELL281 elements. Different mesh options were considered. From the point of view of convergence and calculation speed, a mesh with grinding in the contact zone is preferable. The size and type of mesh significantly affects the analysis results.

The load in the form of two concentrated forces $\mathrm{F}=1,25 \mathrm{kN}$ (Figure 2a) was adopted in accordance with the recommendations of the National Standart "Wooden Structures".

The joint was made in the middle of the span.

The design is a composite. Wood is defined as an orthotropic material with the following characteristics: elastic modulus along the $\mathrm{x}$ axis, $\mathrm{E}_{\mathrm{x}}=$ $1.1 \times 10^{10} \mathrm{~Pa}$; elastic modulus $\mathrm{E}_{\mathrm{y}}=\mathrm{E}_{\mathrm{z}}=4.5 \times 10^{8}$ $\mathrm{Pa}$; Poisson's ratios $v_{\mathrm{xy}}=0.45, v_{\mathrm{yz}}=v_{\mathrm{xz}}=0.018$; shear modulus $\mathrm{G}_{\mathrm{x}}=\mathrm{G}_{\mathrm{y}}=\mathrm{G}_{\mathrm{z}}=6 \times 10^{8} \mathrm{~Pa}$.

The glued rods are carbon fiber on a polymer matrix [23] with the following characteristics: tensile strength at break $\sigma_{\mathrm{t}}=2.248 \times 10^{6} \mathrm{~Pa}$; elastic modulus $\mathrm{E}=117 \times 10^{9} \mathrm{~Pa}$; Poisson's ratio $v_{\mathrm{xy}}=v_{\mathrm{yx}}=0.31$.

The overlays are defined as a transversally isotropic bidirectional carbon fiber reinforced plastic with a direction of reinforcing layers of \pm 45 degrees with the following characteristics: tensile strength at break $\sigma_{\mathrm{t}}=7.65 \times 10^{6} \mathrm{~Pa}$; elastic moduli $\mathrm{Ex}=\mathrm{Ey}=87.2 \times 10^{9} \mathrm{~Pa}, \mathrm{Ez}=65.4 \times$ $10^{9} \mathrm{~Pa}$; Poisson's ratios $v_{\mathrm{xy}}=v_{\mathrm{yx}}=0.268 ; v_{\mathrm{xz}}=$ 0.018 .

Numerical implementation of nonlinear problems of determining the stress-strain state of a structure was carried out by a step-by-step method by replacing the entire load with a series of its small increments. Within each loading step, the load can be further divided into several solution steps to ensure gradual application of the load. At each step of the solution, to obtain 
Numerical Modelling and Full-Scale Experiments of Glued Wooden Structures Joint Destruction of Carbon-Fiber Dowel Pins

convergence, equilibrium iterations were performed using the Newton-Raphson method. The convergence check for forces and displacements was carried out using the Euclidean norm for all degrees of freedom.

\section{RESULTS AND DISCUSSION}

The results of calculating a variant of a beam with arrangement at the junction of eight pins on each side at an angle of $45^{\circ}$ to a line running along the long edge of the beam are shown. Figures 3 and 4 show the isofield of the distribution of equivalent stresses in wood and connecting parts (pads and rods).
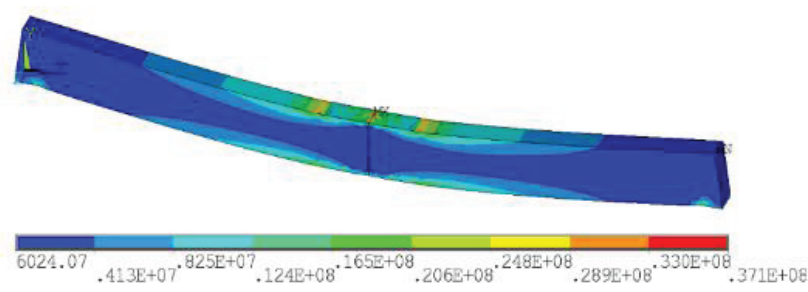

Figure 3. Isofields of stress distribution in the body of wood $(\mathrm{Pa})$.

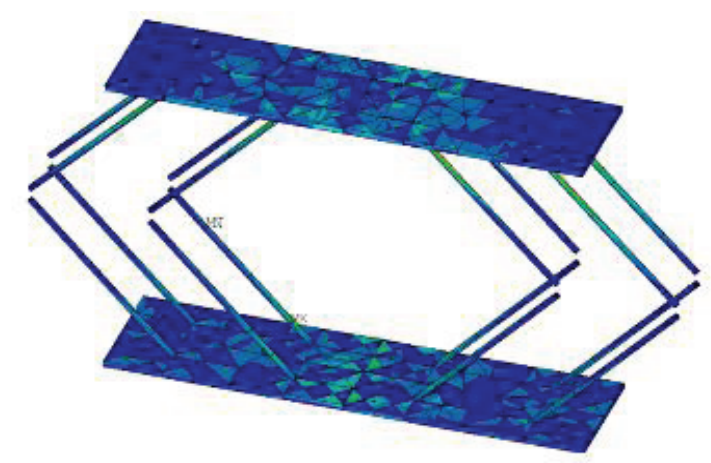

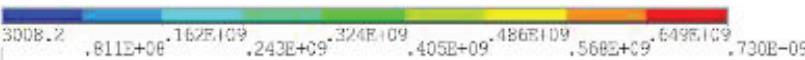
Figure 4. Isofields of the stress distribution in connecting parts $(\mathrm{Pa})$.

The contact interaction status of structural elements is shown in Figure 5 (orange color indicates slippage of wood layers relative to each other ("SLIDING" in ANSYS terminology), as well as slippage of rods in landing slots at the moment of sample destruction).
Plastic deformations in a specimen with a rigid joint begin to form under the supports of the beam in the zone of maximum bending moment at a load of $15.4 \mathrm{kN}$. A diagram with the locations of the resulting plastic hinges is shown in Figure 6. The failure of the joint occurs at a load of $25.6 \mathrm{kN}$. In this case, the opening of the joint zone and the separation of the connecting strips, as well as the rods at the contact points.

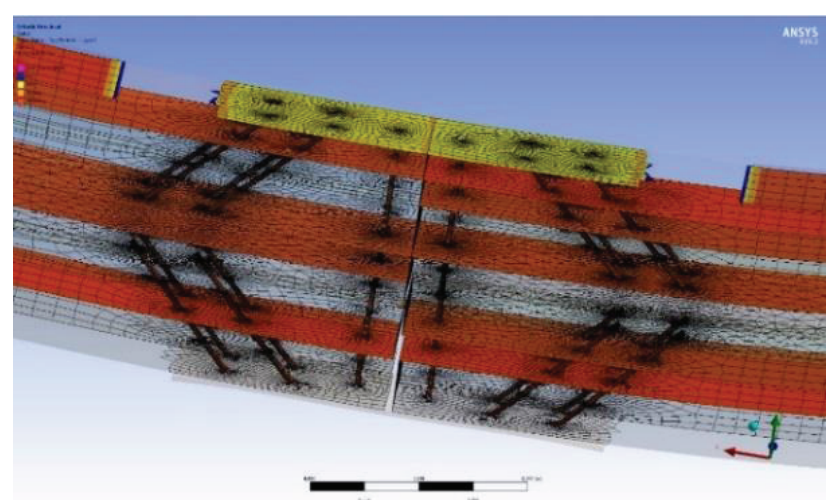

Figure 5. Contact interaction of the rods, pads and layers of wood at the time of destruction.

The maximum equivalent stresses in the glued rods forming a rigid joint were $600.7 \mathrm{MPa}$. The voltage distribution fields in the connecting parts are shown in Figure 6.

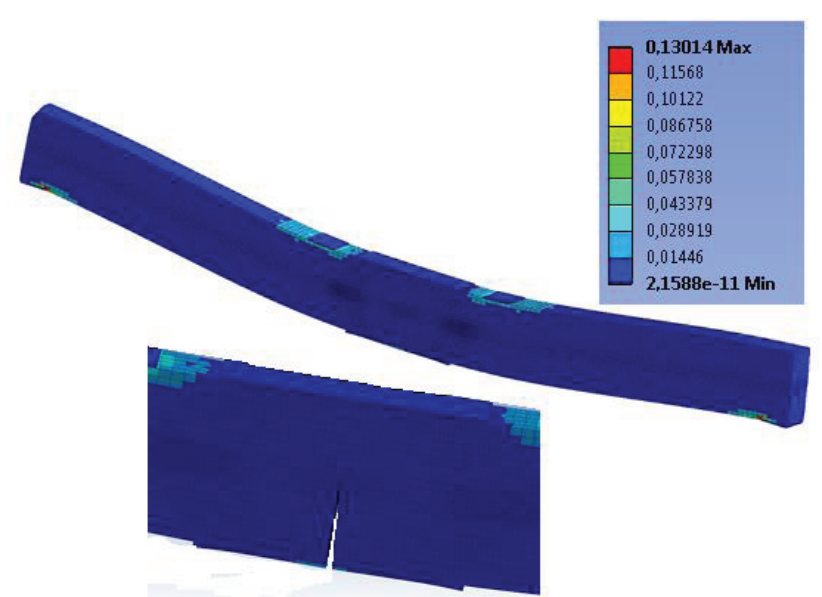

Figure 6. Plots at the beginning of the formation of plastic hinges under the supports of the beam.

At the moment of sample destruction, the maximum displacements of the middle of the beam 
span (at the junction) according to the results of numerical simulation were equal to $9.75 \mathrm{~mm}$.

The maximum equivalent stresses in the glued rods forming a rigid joint were $600.7 \mathrm{MPa}$. The voltage distribution fields in the connecting parts are shown in Figure 7.

The most responsible (bottleneck) is the area of glued rods located between the plate and the wood - in this place the greatest bending stresses arise. In Figure 7, these areas are painted in light blue. When designing the joint, it is advisable to use conical-shaped rods with a thickening at the junction of the parts to be joined.

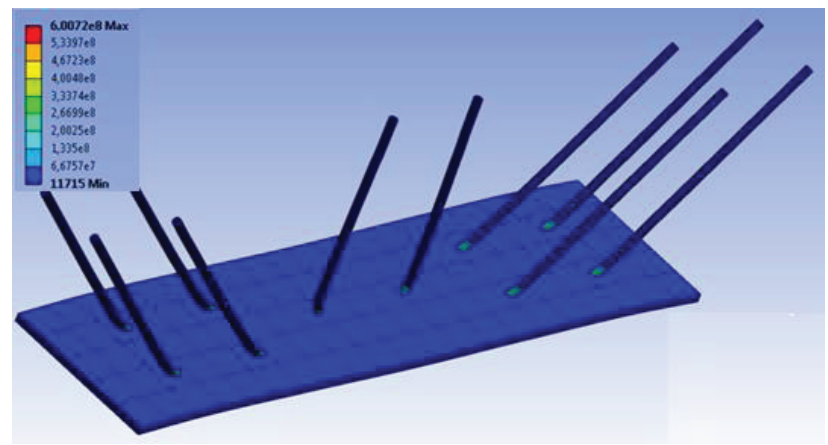

Figure 7. Isofields and stresses in the rods on a stretched pad.

In order to assess the influence of the parameters of structural elements on the bearing capacity of the joint and to determine the most loaded rod in the joint, a multivariate computational experiment was conducted. The following parameters were taken as variable: position (gluing angle) $\varphi=15,30,45,60^{\circ}$ (Figure 8); the number of pins in the connection $\mathrm{N}=4,8$, or 12 pcs.

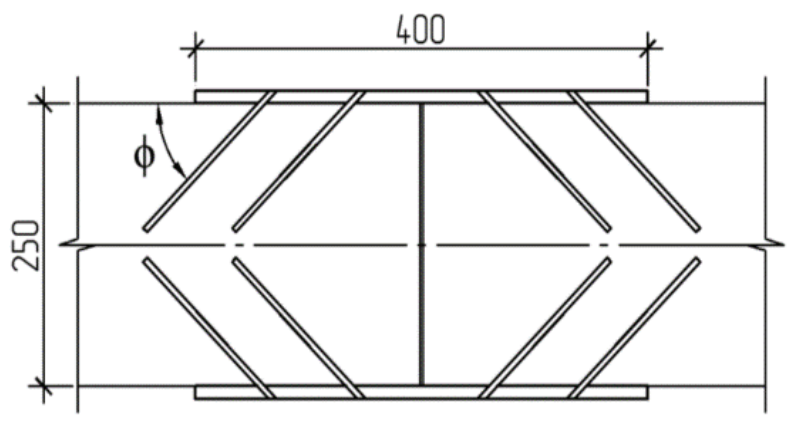

Figure 8. The angle of gluing rods.
The rods are installed in two longitudinal rows, the location of the rods is taken in accordance with the requirements of paragraphs 7.18, 7.19 [9].

The following are taken as controlled design parameters: maximum equivalent stresses before failure for all joints: in wood, in rods, in overlays and maximum beam deflection in the vertical plane.

The following are taken as controlled design parameters: maximum equivalent stresses before failure for all joints: in wood, in rods, in overlays and maximum beam deflection in the vertical plane.

The results obtained during the computational experiments are shown in Figures 9-12.

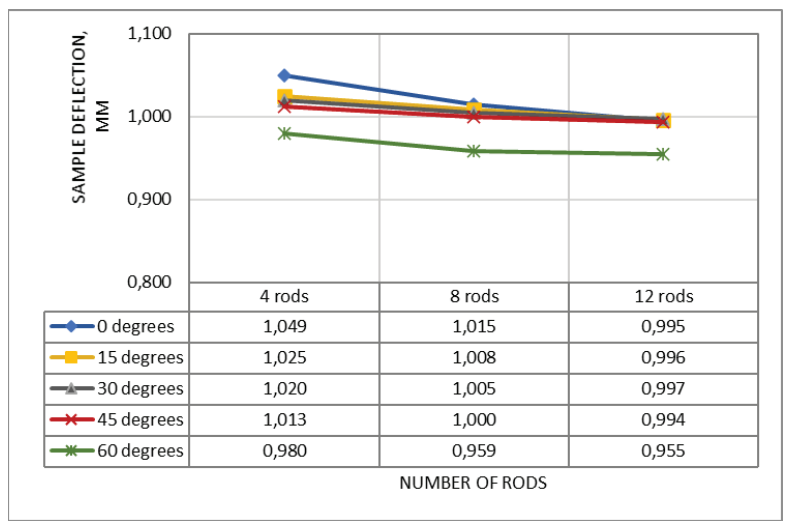

Figure 9. Deflection of the beam in the vertical plane.

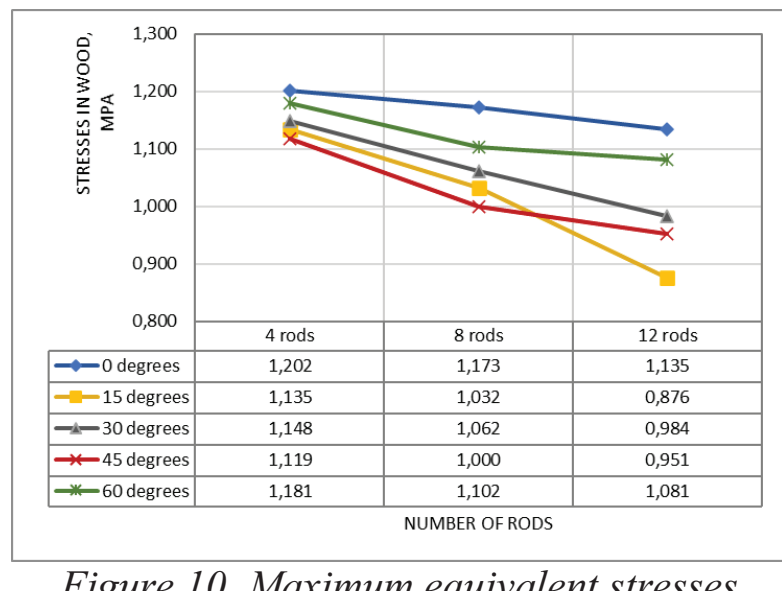

Figure 10. Maximum equivalent stresses in wood.

It can be seen from the graphs that the beam deflection decreases with an increase in the angle of inclination of the rod (logically, the rods become 
Numerical Modelling and Full-Scale Experiments of Glued Wooden Structures Joint Destruction of Carbon-Fiber Dowel Pins

more parallel to the boards and create longitudinal reinforcement). Stresses in wood and CFRP vary insignificantly, and the stresses in the rods and pads are greater, the smaller the rods.

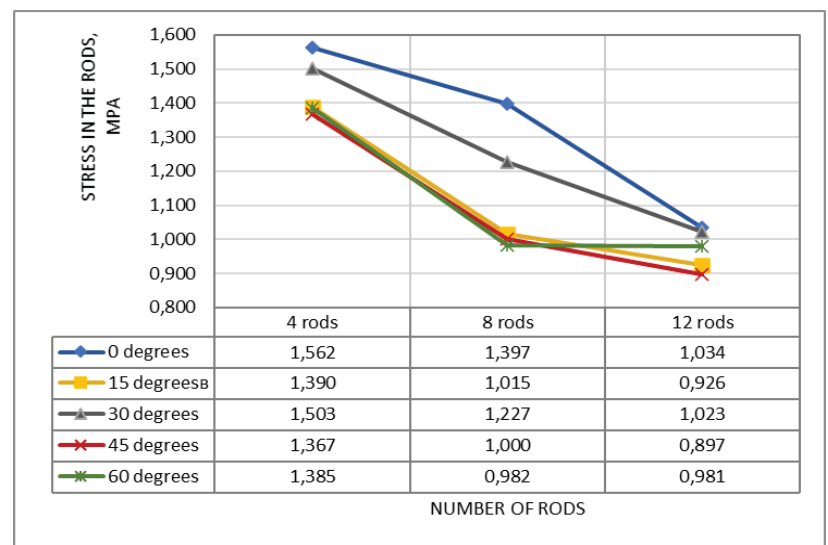

Figure 11. Maximum equivalent stresses in the rods.

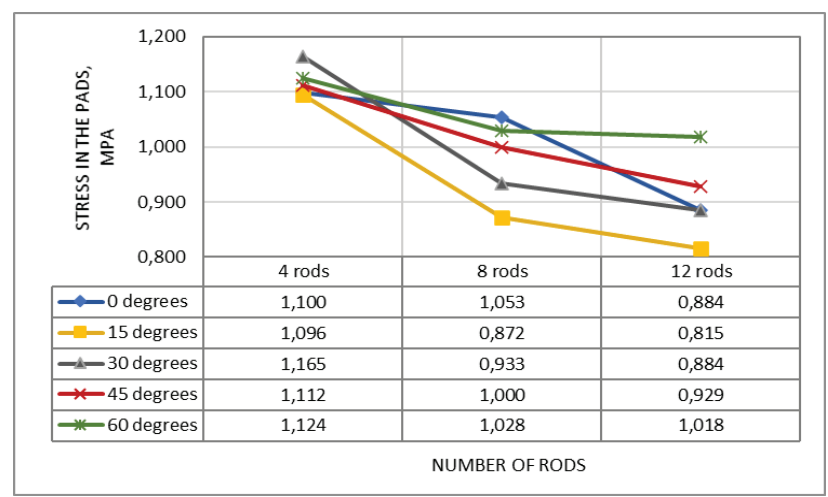

Figure 12. Maximum equivalent stresses in pads.

\section{FULL-SCALE EXPERIMENTS}

The scheme of full-scale testing of the samples corresponded to the design scheme shown in Figure 2. The joint was made in the middle of the span. The beam body is glued wood of the second grade with a section of $100 \times 225 \times 3000 \mathrm{~mm}$. The glued rods are carbon fiber with a diameter of $5 \mathrm{~mm}$, obtained by pultrusion. The overlays on the top and bottom of the beam - bidirectional carbon fiber on the matrix of the synthetic polymer binder are anchored (fixed) into the body of the wood using glued rod.
The tests were carried out until the destruction of the sample stepwise increasing load on a individually designed bench. The pressure on the beam was transmitted by means of a hydraulic jack DU50P250 through a traverse with two articulated supports. The load value was taken from an electronic pressure gauge connected to the oil station via high pressure hoses. The value of the breaking load was taken at the moment at which an increase in displacements was observed with the jack support pressure drop. To measure the displacements, inductive linear displacement sensors DPL-100 were used, connected to the TEREM-4.1 recording unit.

A general view of the beam on the bench is shown in Figure 13. The sample after the destruction of the joint, is shown in Figure 14.

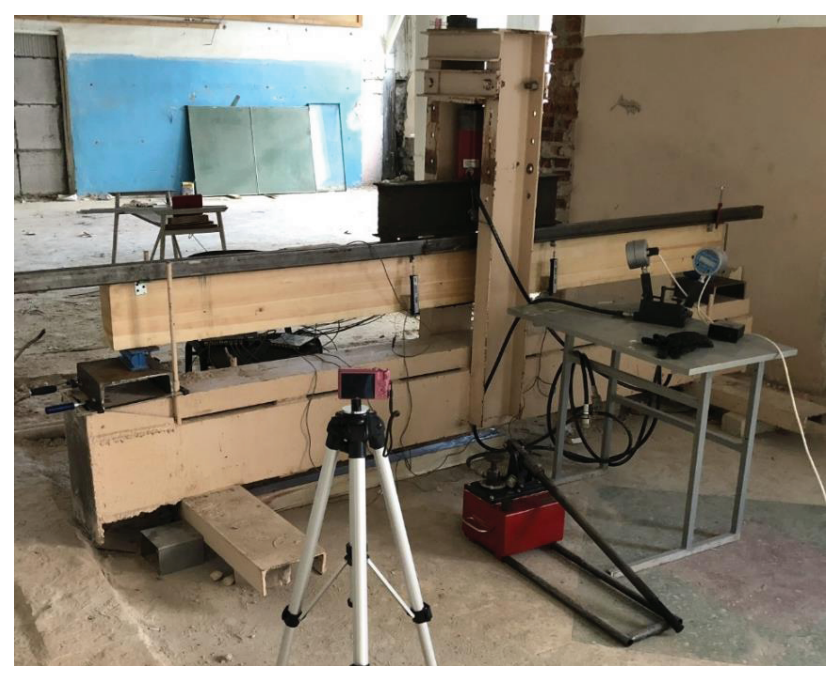

Figure 13. General view of the beam on the bench.

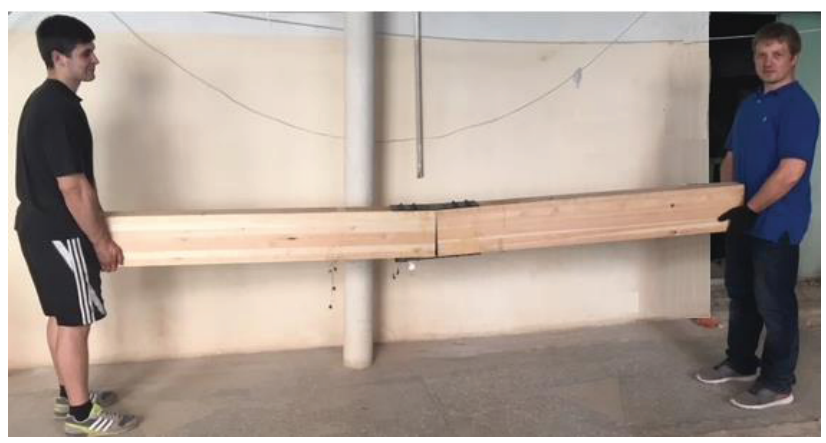

Figure 14. The sample after the destruction of the joint. 
The tests were carried out until the sample was destroyed by a stepwise increasing load on a specially designed bench. The breaking load is set at $25.4 \mathrm{kN}$, the displacement in the middle of the span was $7.2 \mathrm{~mm}$. The compressed (upper) edge of the beam at the junction closely approached the opposite part of the beam, forming a frontal stop. The maximum width of the opening of the lower edge at the junction was noted with an indicator value of $5.7 \mathrm{~mm}$, with an initial gap value of 1 $\mathrm{mm}$ before the test.

Figure 15 shows the graphs of the dependence of the maximum displacements of the beam on the load obtained in computational and field experiments. Sensors "1" and "3" are installed under the support heels of the beam, transmitting the force directly to the beam. Sensor "2" is installed in the middle of the beam span (at the junction).

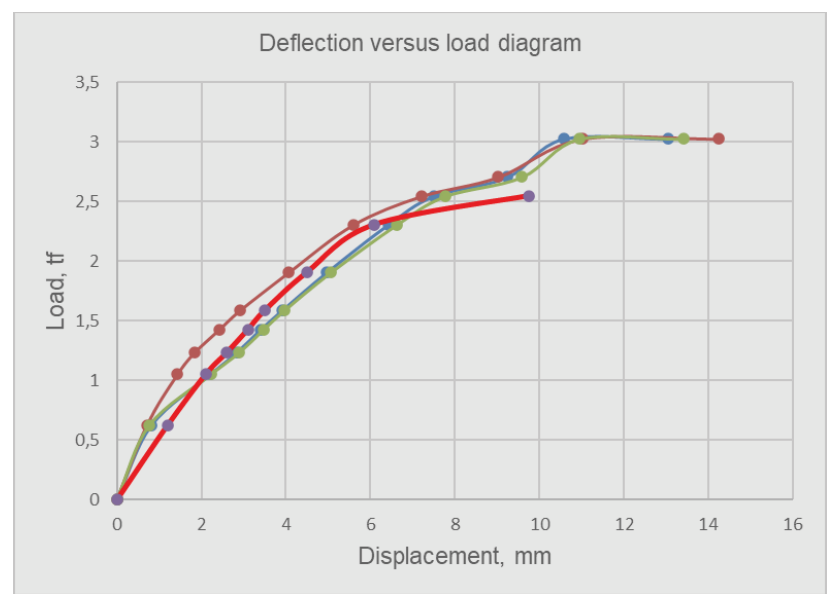

Figure 15. Graphs of the dependence of displacements on load for experimental and theoretical data.

The experiments were carried out until the collapse of the beam and the joint with the occurrence of mutual displacements of the layers of wood and pulling out individual rods. After destruction, the beam did not return to its original state.

The nature of the damage in full-scale tests corresponds to the forecast of the numerical model. The structure is destroyed as a result of the mutual slip of the glued wood layers, the destruction of the polymer matrix of the glued rods, the formation of plastic joints under the heels of the beam and the formation of cracks in the wood at the junction.

After the first rod was turned off from work, the structure continued to work elastically for some time, but with an increase in load and a sharp destruction of the remaining rods, the joint of the structure completely destroyed. This information is confirmed by the spasmodic behavior of the curve on the load-displacement graph, followed by an increase in deformations when the load drops.

\section{CONCLUSION}

The creation of a correct design model for the construction of a wooden beam with a nodal joint, taking into account the orthotropy of glued wood and the contact interaction of the joints, the use of numerical methods and modern software systems, allows us to understand the nature of the destruction of the composite structure, the distribution of stresses and displacements that occur inside the joint, hidden for registration during experimental research.

The places of the most probable destruction of the structure are determined depending on the parameters of the joint design.

The principal possibility of replacing metal parts with carbon fiber to create equal strength joints of wooden structures is shown. When comparing the results of experiments of a beam with a joint on glued rods with a similar continuous beam, the reinforcing effect of the rods is noted, since the glued joint rods prevent mutual displacement of the layers.

Short-term tests as a whole showed viable solutions when designing joints on glued rods [24], however, to complete the picture of the operation of such parts, it is necessary to conduct long-time based experiments, including fire tests and vibration load tests. It is necessary to take into account the aging of composites. Also, a long-time experiment is designed to show the joint work of the composite and wood, because, for example, steel rods form an oxide corrosion shell over time and after several years of opera- 
Numerical Modelling and Full-Scale Experiments of Glued Wooden Structures Joint Destruction of Carbon-Fiber Dowel Pins

tion cease to provide the initial joint work in the wood nests. It is assumed that composite solutions for joints of glued wooden structures will be free from such drawbacks.

\section{REFERENCES}

1. Andreev S.A. Primenenie sterzhnevyh soedinenij $\mathrm{V}$ derevyannyh konstrukciyah [The use of rod joints in wooden structures]. // Strojindustriya, 1930, No. 7 (in Russian).

2. Maslov V.N. Raschet boltovogo, rabotayushchego na razryv styka derevyannoj fermy kak uprugoj sistemy [Calculation of the bolted working on the gap of the wooden truss as an elastic system]. // Collection of works of the Moscow Institute of Engineering Transport, 1926, No. 2, pp. 119-114 (in Russian).

3. Ivanov V.F., Maltsev L.I. Issledovanie raboty nagel'nyh soedinenij $\mathrm{v}$ predelah uprugosti [The study of the work of joint compounds in the range of elasticity]. // Proceedings of the Leningrad Institute of Engineering and Public Construction, 1939, pp. 167-175 (in Russian).

4. Nikolai B.A. Teoriya rascheta nagel'nogo sopryazheniya $\mathrm{v}$ derevyannyh konstrukciyah [Theory of the calculation of the brass mates in wooden structures]. Moscow, NDTVCH, 1935, 164 pages (in Russian).

5. Lenyashin A.V. Issledovanie sopryazhenij na nagelyah: nauchno-tekhnicheskij otchet laboratorii derevyannyh konstrukcij CNIIPS [Conjugation of mates on pins: scientific and technical report of the laboratory of wooden structures TsNIIPS]. Moscow, 1935, No. $4412-5100$ (in Russian).

6. Donchenko V.G., Nagel'nye soedineniya v avtodorozhnyh mostah [Fuse connections in road bridges]. Moscow, Dorizdat, 1952, 255 pages (in Russian).

7. Slitkoukhov Y.V. Issledovanie raboty simmetrichnyh sopryazhenij elementov derevyannyh konstrukcij na nagelyah iz krugloj stali [The study of the symmetric mating elements of wooden structures on the dowel of round steel]. PhD Thesis, 1956, 12 pages (in Russian).

8. Kochenov V.M. Nesushchaya sposobnost' elementov i soedinenij derevyannyh konstrukcij [Bearing capacity of elements and connections of wooden structures]. Moscow, Gosstroiizdat, 1953, 320 pages (in Russian).

9. SP 64.13330.2017. Derevyannye konstrukcii. Aktualizirovannaya redakciya SNiP II-25-80 [Wooden structures. Updated edition]. Moscow, TSNIISK, 2017, 87 pages (in Russian).

10. Turkovskij S.B., Sayapin V.V. Issledovanie montazhnyh uzlovyh soedinenij kleyonyh derevyannyh konstrukcij [Investigation of assembly nodal joints of glued wooden structures]. // Bearing wooden structures: Collection of scientific papers. Moscow, TSNIISK, 1981, pp. 92-105 (in Russian).

11. Turkovskij S.B., Lomakin A.D. Pogorel'cev A.A., Zavisimost' sostoyaniya kleenyh derevyannyh konstrukcij ot vlazhnosti okruzhayushchego vozduha [Dependence of the state of glued wooden structures on the humidity of the surrounding air]. // Industrial and Civil Engineering. Institute Proceedings, Moscow, TSNIISK, 2012, No. 3, pp. 30-32 (in Russian).

12. Turkovskij S.B., Pogorel'cev A.A. Sozdanie derevyannyh konstrukcij sistemy TSNIISK na osnove naklonno vkleennyh sterzhnej [Creation of wooden structures of the TSNIISK system based on inclined glued rods]. // Industrial and Civil Engineering. Institute Proceedings. Moscow, TSNIISK, 2007, No. 3, pp. 6-8 (in Russian).

13. Turkovskij S.B., Pogorel'cev A.A. Preobrazhenskaya I.P. Kleenye derevyannye konstrukcii $\mathrm{s}$ uzlami na vkleennyh sterzhnyah $\mathrm{V}$ sovremennom stroitel'stve (sistema CNIISK) [Glued wooden structures with knots on the glued 
rods in modern construction (TSNIISK system)]. Moscow, Strojmaterial,. 2013, 308 pages (in Russian).

14. Kashevarova G. G., Vodiannikov M.A. Chislennoe i eksperimental'noe modelirovanie zhestkogo styka sloistyh derevyannyh konstrukcij [Numerical and experimental modeling of hard joints of laminated wooden structures]. // International Journal for Computational Civil and Structural Engineering, 2017, Volume 13, Issue 2, pp. 8492 (in Russian).

15. Vodiannikov M., Kashevarova G. Analysis of Wood Structure Connections Using Cylindrical Steel and Carbon Fiber Dowel Pins. // IOP Conference Series: Materials Science and Engineering, 2017, Volume 205.

16. Gugutsidze G., Draskovic F. Reinforcement of Timber Beams with Carbon Fiber Reinforced Plastics. // Slovak Journal of Civil Engineering, 2010, No. 2, pp. 1-6.

17. Mett'yuz F., Rolings R. Kompozitnye materialy. Mekhanika i tekhnologiya [Composite materials. Mechanics and technology]. Moscow, Tehnosfera, 2004, 408 pages (in Russian).

18. Kaplun A. B. ANSYS v rukah inzhenera. Prakticheskoe rukovodstvo [ANSYS in the hands of an engineer. Practical guide]. Moscow, Librokom, 2015, 272 pages (in Russian).

19. Stankevich I. V., Yakovlev M. E., Si Tu Htet. Matematicheskoe modelirovanie kontaktnogo vzaimodejstviya uprugoplasticheskih sred [Mathematical modeling of the contact interaction of elastoplastic media]. Moscow, NEIKON, 2012 (in Russian).

20. Mashkov Y.K. Tribofizika metallov i polimerov [Tribophysics of metals and polymers]. Omsk, OMGTU Publishing, 2013, 240 pages (in Russian).

21. Popov V.L. Mekhanika kontaktnogo vzaimodejstviya i fizika treniya. Ot nanotribologii do dinamiki zemletryasenij [Mechanics of contact interaction and physics of friction. From nanotribology to earth- quake dynamics]. Moscow, Fizmatlit, 2013, 352 pages (in Russian).

22. Podgornyj A.N., Gontarovskij P.P. and others. Zadachi kontaktnogo vzaimodejstviya elementov konstrukcij. Monografiya [Tasks of contact interaction of structural elements]. Kiev, Nauk Dumka, 1989, 232 pages (in Russian).

23. Perepelkin K.E. Himicheskie volokna: razvitie proizvodstva, metody polucheniya, svojstva, perspektivy [Chemical fibers: production development, production methods, properties, prospects]. SaintPetersburg,. SPGUTD Publishing, 2008, 354 pages (in Russian).

24. Vodiannikov M., Kashevarova G. Composite Solutions for Glulam Joints. // Key Engineering Materials, 2019, Volume 801.

\section{СПИСОК ЛИТЕРАТУРЫ}

1. Андреев, С.А. Применение стержневых соединений в деревянных конструкциях. // Стройиндустрия, 1930, №7.

2. Маслов В.Н. Расчет болтового, работающего на разрыв стыка деревянной фермы как упругой системы. // Сборник трудов Московского института инженеров транспорта, 1926, Выпуск 2, с. 114119.

3. Иванов В.Ф., Мальцев Л.И. Исследование работы нагельных соединений в пределах упругости. // Труды Ленинградского института инженеров коммунального строительства, 1939, с. 167-175.

4. Николаи Б.А. Теория расчета нагельного сопряжения в деревянных конструкциях. - М.: НДТВЧ, 1935. - 164c.

5. Леняшин А.В. Исследование сопряжений на нагелях: научно-технический отчет лаборатории деревянных конструкций ЦНИИПС. Москва, 1935, №44125100.

6. Донченко В. Г. Нагельные соединения в автодорожных мостах. - М.: Дориздат, 1952. $-255 \mathrm{c}$. 
Numerical Modelling and Full-Scale Experiments of Glued Wooden Structures Joint Destruction of Carbon-Fiber Dowel Pins

7. Слицкоухов Ю.В. Исследование работы симметричных сопряжений элементов деревянных конструкций на нагелях из круглой стали. Автореферат диссертации на соискание ученой степени кандидата технических наук. - М., 1956. - 12 с.

8. Коченов В.М. Несущая способность элементов и соединений деревянных конструкций. - М.: Госстройиздат, 1953. $-320 \mathrm{c}$.

9. СП 64.13330.2017. Деревянные конструкции. Актуализированная редакция СНиП II-25-80. ЦНИИСК им. В.А. Кучеренко - институт ОАО «НИЦ «Строительство». - М., 2011. - 87 с.

10. Турковский С.Б., Саяпин В.В. Исследование монтажных узловых соединений клеёных деревянных конструкций. // Hесущие деревянные конструкции: Сборник научных трудов. - М.: ЦНИИСК им. Кучеренко, 1981, с. 92-105.

11. Турковский С.Б., Ломакин А.Д. Погорельцев А.А. Зависимость состояния клееных деревянных конструкций от влажности окружающего воздуха. // Промышленное и гражданское строительство. Труды института. - М.: ЦНИИСК им. В.А. Кучеренко, 2012, №3, c. 30-32.

12. Турковский С.Б., Погорельцев А.А. Создание деревянных конструкций системы ЦНИИСК на основе наклонно вклеенных стержней. // Промышленное и гражданское строительство. Труды института. - М.: ЦНИИСК им. В.А. Кучеренко, 2007, №3, с. 6-8.

13. Турковский С.Б., Погорельцев А.А. Преображенская И.П. Клееные деревянные конструкции с узлами на вклеенных стержнях в современном строительстве (система ЦНИИСК). - М.: РИФ «Стройматериалы», 2013. - 308 с.

14. Кашеварова Г. Г., Водянников М.А. Численное и экспериментальное моделирование жесткого стыка слоистых деревянных конструкций // International Journal for Computational Civil and
Structural Engineering, 2017, Volume 13, Issue 2, pp. 84-92.

15. Vodiannikov M., Kashevarova G. Analysis of Wood Structure Connections Using Cylindrical Steel and Carbon Fiber Dowel Pins // IOP Conference Series: Materials Science and Engineering, 2017, Volume 205.

16. Gugutsidze G., Draskovic F. Reinforcement of Timber Beams With Carbon Fiber Reinforced Plastics. // Slovak Journal of Civil Engineering, 2010, No. 2, pp. 1-6.

17. Мэттьюз Ф., Ролингс Р. Композитные материалы. Механика и технология. - М: Техносфера, 2004. - 408 c.

18. Каплун, А.Б., Морозов Е.М., Олферьева M.A. ANSYS в руках инженера. Практическое руководство. - М.: Либроком, 2015. - $272 \mathrm{c}$.

19. Станкевич И. В., Яковлев М. Е., Си Ту Хтет. Математическое моделирование контактного взаимодействия упругопластических сред. - М.: НП «Неикон», 2012.

20. Машков Ю.К. Трибофизика металлов и полимеров: монография. - Омск: Издательство ОмГТУ, 2013. - 240 с.

21. Попов В.Л. Механика контактного взаимодействия и физика трения. От нанотрибологии до динамики землетрясений. - М.: ФИЗМАТЛИТ, 2013. - 352 с.

22. Подгорный А.Н., Гонтаровский П.П. и др. Задачи контактного взаимодействия элементов конструкций. - Киев: Наукова Думка, 1989. - 232 с.

23. Перепелкин К. Е. Химические волокна: развитие производства, методы получения, свойства, перспективы - СПб.: Издание СПГУТД, 2008. - 354 с.

24. Vodiannikov M., Kashevarova G. Composite Solutions for Glulam Joints. // Key Engineering Materials, 2019, Volume 801.

Mikhail A. Vodiannikov, Engineer of the department for survey and monitoring of building structures of JSC "VNII Galurgii"; Graduate Student, Department of Building Constructions and Computational Mechanics, Perm National 
Research Polytechnic University; 29, Komsomolsky prospect, Perm, 614990, Russian Federation;

email: vodyannikov@mail.ru.

Galina G. Kashevarova, Corresponding Member of Russian Academy of Architecture and Construction Sciences (RAACS), Professor, Dr.Sc., Head of department "Building constructions and computational mechanics", Perm National Research Polytechnic University; Russia, 614010, Perm, ul. Kuibyshev, 109; phone +7 (342) 219-83-61;

E-mail: ggkash@mail.ru.

Danil I. Starobogatov, Part-time professor at Durham College, Ontario, Canada; 1610 Champlain Avenue Whitby, ON, Canada L1N 6A7;

E-mail: dstarobogatov@gmail.com.

Водянников Михаил Алексеевич, аспирант кафедры «Строительные конструкции и вычислительная механика» Пермского национального исследовательского политехнического университета; Инженер отдела обследования и мониторинга строительных конструкций АО «ВНИИ Галургии»; 614990, Россия, г. Пермь, Комсомольский проспект, д. 29;

тел./факс: +7 (342) 2-198-361;

E-mail: vodyannikov@mail.ru.

Кашеварова Галина Геннадьевна, член-корреспондент Российской академии архитектуры и строительных наук (РААСН), доктор технических наук, профессор, заведующая кафедрой «Строительные конструкции и вычислительная механика» Пермского национального исследовательского политехнического университета; 614010, Россия, г. Пермь, ул. Куйбышева, 109; тел. +7(342) 219-83-61; e-mail: ggkash@mail.ru.

Старобогатов Данил И., профессор Durham College, Ontario, Canada; 1610 Champlain Avenue Whitby, ON, Canada L1N6A7; e-mail: dstarobogatov@gmail.com. 